\title{
A search for nitrosamines in East African spirit samples from areas of varying oesophageal cancer frequency
}

\author{
C. H. COllis, PAUla J. COOK, J. K. FOREMAN, AND J. F. PAlfRAMAN
}

From Guy's Hospital Medical School, London, the Statistical Research and Services Unit, University College Hospital Medical School, London, and the Laboratory of the Government Chemist, Cornwall House, Stamford Street, London

SUMMARY Following the report of the presence of nitrosamine-like substances in samples of homemade spirit from Zambia, which had been obtained from an area where cancer of the oesophagus is common, samples of distilled alcoholic drinks were collected throughout western Kenya and southern Uganda from areas where the frequency of cancer of the oesophagus varies from very common to very rare. The 44 samples of spirit were screened by polarography and substances giving a similar response to nitrosamines were indicated at levels as high as $21 \mathrm{ppm}$. Subsequent analysis by gas chromatography for selected individual nitrosamines showed no evidence for the occurrence of methylethylnitrosamine (MEN), diethylnitrosamine (DEN), dipropylnitrosamine (DPN), ethylbutylnitrosamine (EBN), dibutylnitrosamine (DBN), nor of $\mathrm{N}$ nitrosopiperidine (N Pipn), but traces of compounds having a similar retention time as dimethylnitrosamine (DMN) were observed. However, subsequent examination by mass spectrometry showed no evidence of dimethylnitrosamine. There was no apparent association between the levels of unknown constituents indicated by polarography and gas chromatography, nor between either of these levels and the frequency of cancer of the oesophagus. The results by gas chromatography and mass spectrometry confirm that polarography is too unspecific to be a useful indicator of nitrosamines.

Cancer of the oesophagus shows dramatic variation in frequency within East Africa. In western Kenya it is the commonest type of cancer in men (Ahmed, 1966; Ahmed and Cook, 1969), whilst a few hundred miles away in parts of Uganda and Tanzania it is hardly ever seen (Davies, Knowelden, and Wilson, 1965; Eshleman, 1966; Williams, 1966; Buckley, 1967; Cook and Burkitt, 1971). The local pattern of variation in East Africa reflects the global distribution of cancer of the oesophagus which shows a greater range of incidence throughout the world than any other widely occurring cancer (Doll, 1967).

Various studies have indicated that alcoholic drinks are involved in the aetiology (Higginson and Oettle, 1960; Burrell, 1962; Clemmesen, 1965; Martinez, 1969), but that the mere quantity of alcohol consumed cannot be responsible for the global pattern of incidence (Doll, 1967). In East Africa beer and spirits are widely consumed in areas of both high and low frequency.

Received for publication 5 October 1971.
Various nitrosamine compounds have caused oesophageal tumours in experimental animals (Magee and Barnes, 1956; Magee and Barnes, 1967), and, following a report from a high incidence area of Zambia that nitrosamine-like substances had been found in home-made spirits distilled from a fermentation of maize husks and sugar (McGlashan, Walters, and McLean, 1968), samples of alcoholic drinks were collected from a range of areas in East Africa where cancer of the oesophagus occurs with moderate and low frequency (Cook and Burkitt, 1970). The samples were collected from the areas around the hospitals shown in Fig. 1 with the help of local medical assistants.

\section{Analysis}

The samples were given a preliminary screening by polarography using the methods described for the original Zambian samples (Walters, Johnson, and Ray, 1970) and reduction waves occurred which, if due to nitrosamines, represented concentrations 


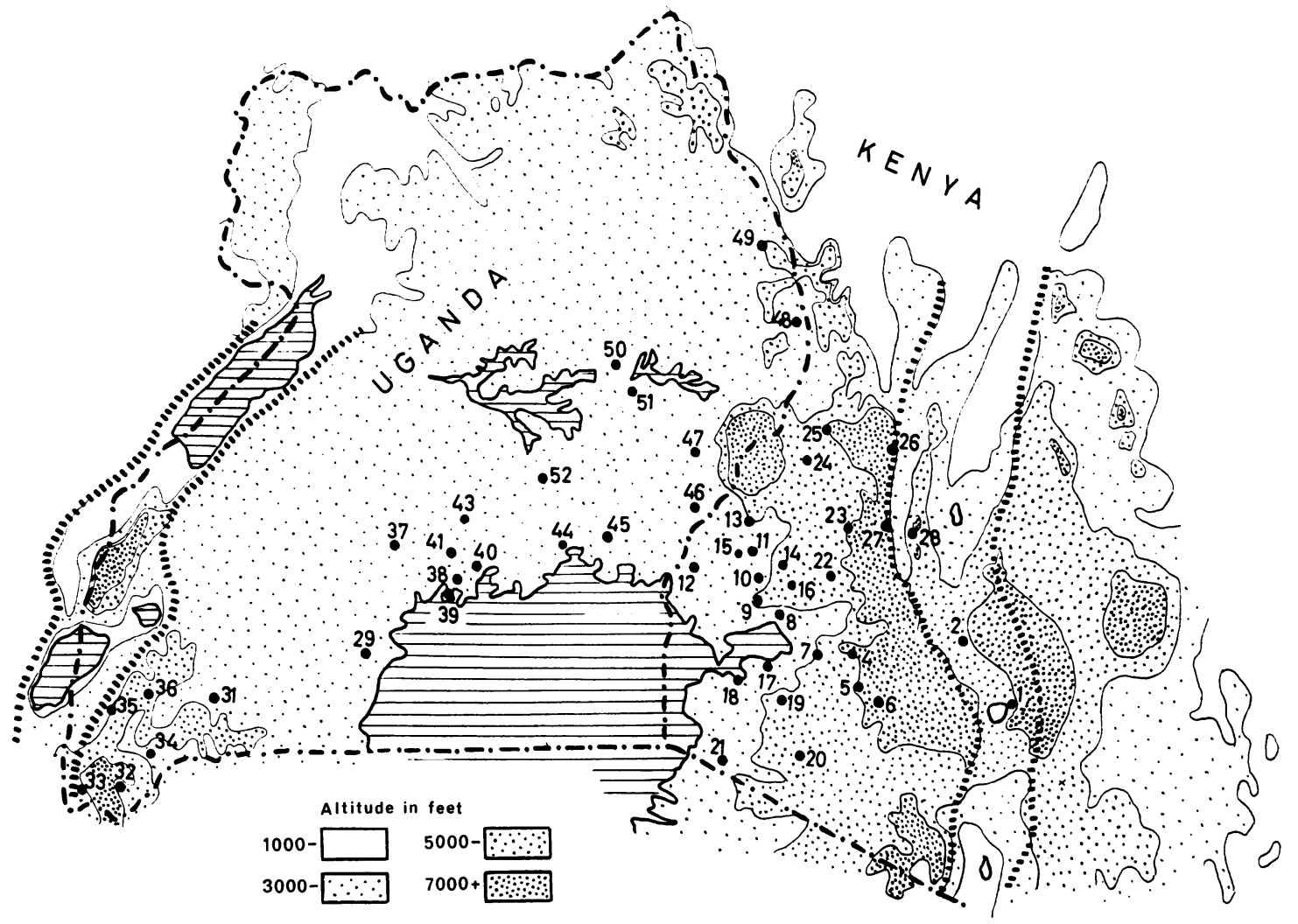

Fig. 1 Hospitals visited in the course of the survey

$\begin{array}{ll}1 \text { Naivasha } & 25 \text { Kapengoria } \\ 2 \text { Nakuru } & 26 \text { Kapsowar } \\ 4 \text { Kenya Tea Co. (Kericho) } & 27 \text { Kabarnet } \\ 5 \text { Tenwek } & 28 \text { Tambach } \\ 6 \text { Kaplong } & 29 \text { Kitovu } \\ 7 \text { Nyabondo } & 31 \text { Mbarara } \\ 8 \text { Kisumu } & 32 \text { Kabale } \\ 9 \text { Maseno } & 33 \text { Mutolere } \\ 10 \text { Mwihila } & 34 \text { Kisiizi } \\ 11 \text { Mumias } & 35 \text { Nyakibale } \\ 12 \text { Nangina } & 36 \text { Ishaka } \\ 13 \text { Bungoma } & 37 \text { Mityana } \\ 14 \text { Kakamega } & 38 \text { Kisubi } \\ 15 \text { Makumu } & 39 \text { Entebbe 'A' } \\ 16 \text { Kaimosi } & 40 \text { Mengo } \\ 17 \text { Kendu } & 41 \text { Nsambya } \\ 18 \text { Homa Bay } & 43 \text { Bombo } \\ 19 \text { Kisii } & 44 \text { Jinja } \\ 20 \text { Kilgoris } & 45 \text { Iganga } \\ 21 \text { Migori-Nyanza Mines } & 46 \text { Tororo } \\ 22 \text { Kapsabet } & 47 \text { Mbale } \\ 23 \text { Eldoret } & 48 \text { Amudat } \\ 24 \text { Kitale } & 49 \text { Moroto } \\ \text { S } & 50 \text { Soroti } \\ & 51 \text { Ngora } \\ & 52 \text { Kamuli }\end{array}$

up to 21 parts per million. However, polarography is known to be non-specific and can give erroneously high results. McGlashan and colleagues have sub- sequently pointed out the dangers of relying on polarography (McGlashan, Patterson, and Williams, 1970). Analyses were therefore carried out using gas chromatography and mass spectrometry. The samples were initially concentrated on a commercial spinning-band distillation column giving concentration factors $(\times 50)$ and at the same time removing the alcohol. The concentrates were then analysed by gas chromatography using specific detectors which enhance the relative response to nitrogenous compounds.

Independent analysis of individual samples would have been excessively time-consuming, and samples were therefore grouped so that those from areas of similar cancer frequency could be treated as composite samples.

All bulked samples giving an apparent indication of nitrosamines by gas chromatography were further examined by combined gas chromatography and mass spectrometry, in which characterization was verified by use of a high resolution instrument (AEI MS 902) to monitor the parent ions of individual nitrosamines. Attention has been confined to the steam volatile lower molecular weight dialkyl 
$\mathrm{N}$ nitrosamines, and the heterocyclic $\mathrm{N}$ nitrosopiperidine. Since the spirits are themselves distillates it is unlikely that non-volatile nitrosamines would be present.

Full details of the analytical methods used and developed at the Laboratory of the Government Chemist will be published elsewhere.

\section{Results and Discussion}

Table I shows the apparent nitrosamine content of the spirit samples from the analysis by gas chromatography and mass spectrometry. Recoveries from standard solutions and from spiked samples have varied from $50 \%$ to nearly $100 \%$; the figures quoted in Table $I$ assume $100 \%$ recovery.

The gas chromatography values quoted assume that any peak with a retention time similar to a nitrosamine is wholly nitrosamine. If when using the instrument at maximum sensitivity no peak of a retention time similar to a nitrosamine was observed, the result is reported as 'not detected' (ND). The peaks for all the nitrosamines except DMN were less than $0.1 \mathrm{ppm}$ or not detected. When a peak of the same retention time as DMN was greater than $0.1 \mathrm{ppm}$, the bulked sample was examined by mass spectrometry.

Bulk samples A-H were concentrated $(\times 50)$ from $25 \mathrm{ml}$ to $0.5 \mathrm{ml}$. Under optimum conditions the mass spectrometer can detect DMN at a level of $5 \mathrm{ppm}$ in such a sample concentrate (equivalent to $0 \cdot 1 \mathrm{ppm}$ in the original sample). Sample 1 was a composite of three samples from a very high incidence area and $150 \mathrm{ml}$ of sample was concentrated to $0.5 \mathrm{ml}$ ( $\times 300)$; in this case the mass spectrometer was capable of detecting DMN equivalent to $0.02 \mathrm{ppm}$ in the original sample. Samples $J$ and $K$ were individual ones in which $50 \mathrm{ml}$ was concentrated to $0.5 \mathrm{ml}(\times 100)$. No DMN was detected in any of the samples.

Table II shows the values obtained during the original general screening by polarography.

The levels of frequency of cancer of the oesophagus indicated in Tables I and II vary from 20 to $25 \%$ of all tumours diagnosed in men in the 'high' frequency area to less than $1 \%$ in the areas of 'very low' frequency (Cook and Burkitt, 1971; Cook and Burkitt, 1970). There is no apparent association between the gas chromatographic and the polarographic results and no association between the levels of unknown constituents indicated by the two methods and the occurrence of cancer of the oesophagus.

The time lag between receiving the samples and the final mass spectrometry/gas chromatography analysis was 16 months. During this time the samples were stored in a cold room $\left(10^{\circ} \mathrm{C}\right)$ in amber-coloured bottles. Polarographic analysis was carried out at the beginning and end of the exercise and no significant differences were observed.

\begin{tabular}{|c|c|c|c|c|c|c|c|c|c|c|c|}
\hline \multirow[t]{2}{*}{ Area } & & \multirow[t]{2}{*}{$\begin{array}{l}\text { Frequency of Oeso- } \\
\text { phageal Cancer }\end{array}$} & \multirow[t]{2}{*}{$\begin{array}{l}\text { Sample } \\
\text { Components }\end{array}$} & \multicolumn{7}{|c|}{$\begin{array}{l}\text { Apparent Nitrosamines Content (ppm measured by gas } \\
\text { liquid chromatography) }\end{array}$} & \multirow{2}{*}{$\begin{array}{l}\text { Mass } \\
\text { Spectro- } \\
\text { graphic } \\
\text { DMN } \\
\text { (ppm) }\end{array}$} \\
\hline & & & & $D M N$ & $M E N$ & $D E N$ & $D P N$ & $E B N$ & $D B N$ & $\begin{array}{l}N . N \\
p_{i p}^{n}\end{array}$ & \\
\hline Northern Nyanza & D & High & $\begin{array}{l}12,13,14,15 \\
16^{2}, 22,23,24\end{array}$ & 0.4 & $\mathbf{N D}$ & $<0.1$ & $<0.1$ & ND & ND & ND & ND \\
\hline $\begin{array}{l}\text { Southern Nyanza } \\
\text { Kisii-Kericho } \\
\text { Kenyan Rift Valley }\end{array}$ & $\begin{array}{l}\mathbf{C} \\
\mathbf{B} \\
\mathbf{A}\end{array}$ & $\begin{array}{l}\text { High-moderate } \\
\text { High-moderate } \\
\text { Moderate }\end{array}$ & $\begin{array}{l}7,17,18,21 \\
4,5,6,19,20 \\
1,2,25,26,27 \\
28\end{array}$ & $\begin{array}{r}0.5 \\
<0.1 \\
<0.1\end{array}$ & $\begin{array}{l}\text { ND } \\
\text { ND } \\
\text { ND }\end{array}$ & $\begin{array}{l}<0.1 \\
<0.1 \\
<0.1\end{array}$ & $\begin{array}{l}<0.1 \\
<0.1 \\
<0.1\end{array}$ & $\begin{array}{l}\text { ND } \\
\text { ND } \\
<0 \cdot 1\end{array}$ & $\begin{array}{l}\mathrm{ND} \\
\mathrm{ND} \\
<0 \cdot 1\end{array}$ & $\begin{array}{l}\text { ND } \\
<0.1 \\
<0.1\end{array}$ & $\begin{array}{l}\text { ND } \\
\text { ND } \\
\text { ND }\end{array}$ \\
\hline Buganda & $\mathbf{E}$ & Low-moderate & $\begin{array}{l}29,32 A^{2}, 38 \\
39,40,41,43 A\end{array}$ & 0.8 & ND & $<0.1$ & $<0.1$ & ND & ND & $<0.1$ & ND \\
\hline Southeast Uganda & $\mathbf{G}$ & Low & $\begin{array}{l}43 B^{4}, 44,45,46 \\
47,52\end{array}$ & 0.5 & ND & $<0.1$ & $<0.1$ & $<0.1$ & $<0.1$ & $<0.1$ & ND \\
\hline $\begin{array}{l}\text { Teso-Karamoja } \\
\text { Nkole-Kigezi }\end{array}$ & $\begin{array}{l}\mathbf{H} \\
\mathbf{F}\end{array}$ & $\begin{array}{l}\text { Very low } \\
\text { Very low }\end{array}$ & $\begin{array}{l}48,4950,51 \\
31,32 B, 34,35 \\
36\end{array}$ & $\begin{array}{l}0 \cdot 5 \\
0 \cdot 9\end{array}$ & $\begin{array}{l}\text { ND } \\
\text { ND }\end{array}$ & $\begin{array}{l}<0.1 \\
<0.1\end{array}$ & $\begin{array}{l}<0.1 \\
<0.1\end{array}$ & $\begin{array}{l}\text { ND } \\
\text { ND }\end{array}$ & $\begin{array}{l}\text { ND } \\
\text { ND }\end{array}$ & $\begin{array}{l}\text { ND } \\
\text { ND }\end{array}$ & $\begin{array}{l}\text { ND } \\
\text { ND }\end{array}$ \\
\hline
\end{tabular}

Table I Apparent nitrosamine content of spirit samples

${ }^{1}$ Hospital numbers as in Figure 1.

'Owing to a misdirection about the regional grouping samples 22,23 , and 24 were wrongfully included in the northern Nyanza bulked sample instead of in the Rift Valley bulked sample. If the results had not been negative the samples from these areas would have been regrouped and reanalysed, but in view of the levels observed no further action was taken.

'This sample from Kigezi was imported from the Buganda area.

'This sample from Buganda was imported from southeastern Uganda.

'N-Nitrosamines: dimethyl (DMN); methyl ethyl (MEN); diethyl (DEN); dipropyl (DPN); ethyl butyl (EBN); and dibutyl (DBN).

N. Nitrosopiperidine (N.N.pip ${ }^{\mathbf{n}}$. 


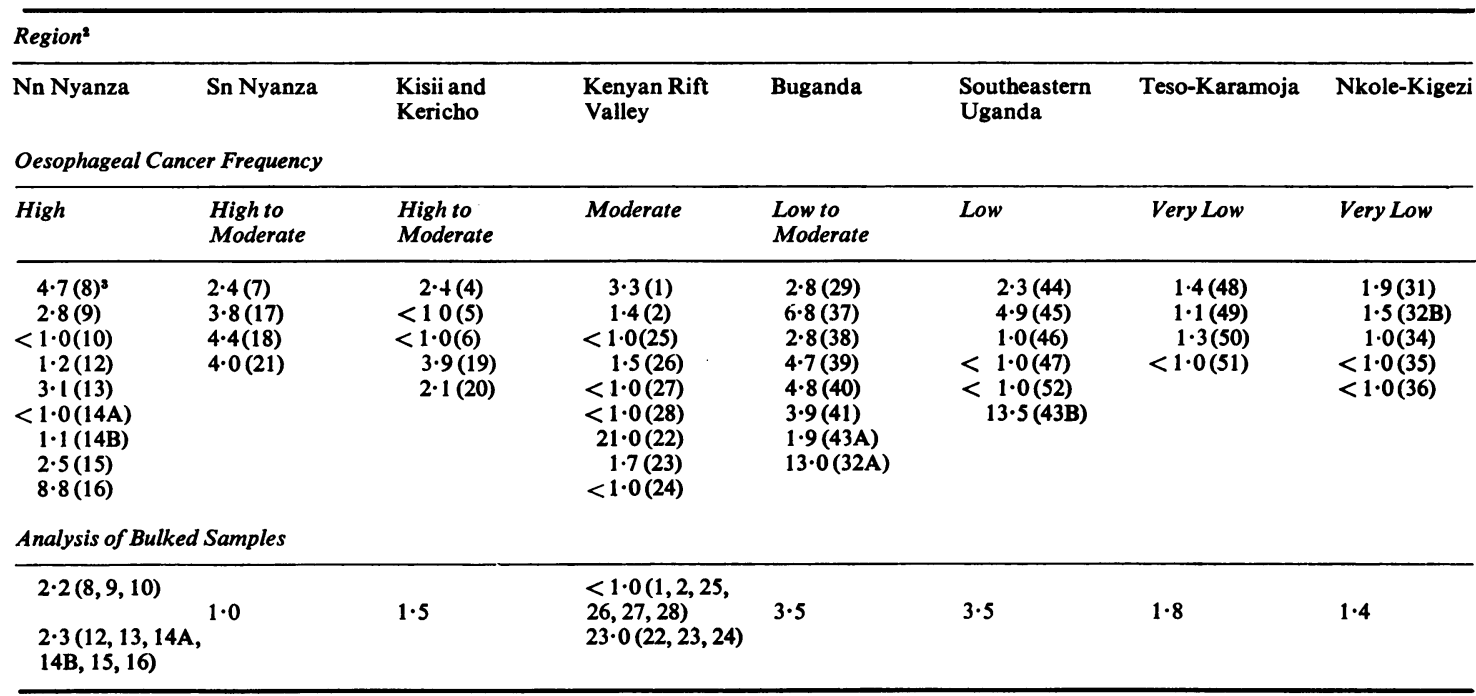

Table II General screening of the spirit samples by polarography 1

'The figures given are an unknown mixture of possible nitrosamines and other contaminants calculated as ppm dimethyl nitrosamine.

'Comparison by region: Kruskal-Wallis one-way analysis of variance (rank test) $x_{7}^{2}=5.98(P>0.05)$

${ }^{8}$ Numbers in brackets identify the hospitals from which the samples were obtained (see Fig. 1).

A standard aqueous solution of DMN (5 ppm) was stored for 12 months under similar conditions without apparent deterioration.

As a final verification, a large sample $(2,000 \mathrm{ml})$ of spirit from a high incidence area was collected and analysed within 10 days of manufacture. A portion of the sample was spiked at source (in Kenya) with a standard nitrosamine solution and analysis of this spiked sample indicated no loss of nitrosamines during transportation. A portion $(500 \mathrm{ml})$ of the sample was concentrated to $0.5 \mathrm{ml}$ ( $\times 100)$ and analysed by gas chromatography and combined gas chromatography/mass spectrometry and as before no nitrosamines were detected. Under these conditions nitrosamines would be detected at a level equivalent to $0.005 \mathrm{ppm}$ in the original sample.

At the same time as the samples were collected methods of preparation and frequency of consumption of different alcoholic drinks in East Africa were investigated by questionnaire. The results of this part of the survey in relation to the frequency of cancer of the oesophagus are being presented elsewhere (Burkitt, Collis, and Cook, 1971).

We thank the Ministries of Health in Kenya and Uganda for permission to carry out the survey and the Government Chemist for permission to publish.

References

Ahmed, N. (1966). Geographical incidence of oesophageal cancer in West Kenya. E. Afr. med.J., 43, 235-248.
Ahmed, N., and Cook, P. (1969). The incidence of cancer of the oesophagus in West Kenya. Brit. J. Cancer, 23, 302-312.

Buckley, R. M. (1967). Patterns of cancer at Ishaka Hospital in Uganda. E. Afr. med. J., 44, 465-468.

Burkitt, D. P., Collis, C. H., and Cook, P. (1971). In preparation.

Burrell, R. J. W. (1962). Esophageal cancer among Bantu in the Transkei. J. nat. Cancer Inst., 28, 495-514.

Clemmesen, J. (1965). Statistical studies in malignant neoplasms. (1) Review and Results. Acta path. microbiol. scand., Suppl., 174.

Cook, P., and Burkitt, D. P. (1970). An epidemiological study of seven malignant tumours in East Africa. (Unpublished report).

Cook, P. J., and Burkitt, D. P. (1971). Cancer in Africa. Brit. med. Bull., 27, 14-20.

Davies, J. N. P., Knowelden, J., and Wilson, B. A. (1965). Incidence rates of cancer in Kyadondo County, Uganda, 1954-1960, J. nat. Cancer Inst., 35, 789-821.

Doll, R. (1967). Prevention of Cancer: Pointers from Epidemiology. Nuffield Provincial Hospitals Trust, London.

Eshleman, J. L. (1966). A study of the relative incidence of malignant tumours seen at Shirati Hospital in Tanzania. E. Afr. med. J., 43, 273-283.

Higginson, J., and Oettle, A. G. (1960). Cancer incidence in the Bantu and Cape Colored races of South Africa: report of a cancer survey in the Transvaal. J. nat. Cancer Inst., 24, 589-671.

McGlashan, N. D., Patterson, R. L. S., and Williams, A. A. (1970). $\mathrm{N}$-nitrosamines and grain-based spirits. Lancet, $2,1138$.

McGlashan, N. D., Walters, C. L., and McLean, A. E. M. (1968). Nitrosamines in African alcoholic spirits and oesophageal cancer. Lancet, 2, 1017.

Magee, P. N., and Barnes, J. M. (1956). The production of malignant primary hepatic tumours in the rat by feeding dimethylnitrosamine. Brit. J. Cancer, 10, 114-122.

Magee, P. N., and Barnes, J. M. (1967). Carcinogenic nitroso-compounds. Advanc. Cancer Res., 10, 163-246.

Martinez, I. (1969). Factors associated with cancer of the oesophagus, mouth, and pharynx in Puerto Rico. J. nat. Cancer Inst., 42, 1069-1094.

Walters, C. L., Johnson, E. M., and Ray, N. (1970). Separation and detection of volatile and non-volatile N-nitrosamines. Analyst, 95, 485-489.

Williams, E. H. (1966). A local cancer registry in a mission hospital in Uganda. E. Afr. med. J., 43, 200-207. 